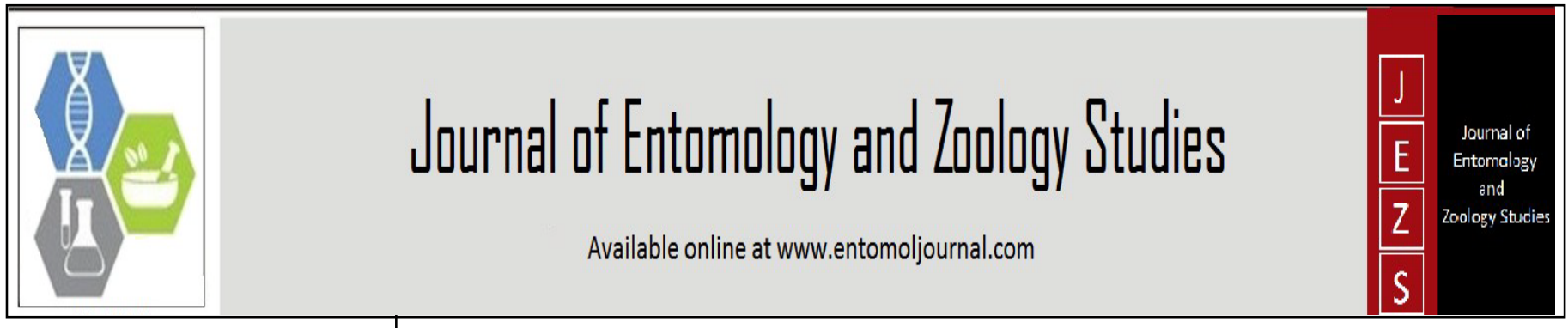

E-ISSN: 2320-7078

P-ISSN: 2349-6800

www.entomoljournal.com

JEZS 2020; 8(6): 854-862

(C) $2020 \mathrm{JEZS}$

Received: 25-08-2020

Accepted: 05-10-2020

Authors Name and Address Given Below
Corresponding Author: Patrick Akono Ntonga Laboratory of Animal Biology and Phsiology, Faculty of Science, Université de Douala. PO Box. 24 157 Douala Cameroon

\section{Biological activities of the essential oils of Cupressus macrocarpa, Lantana camara and Psidium littorale against Plasmodium falciparum welch, 1897 and Anopheles gambiae giles, 1902}

\author{
Gaëlle Magne Tamdem, Patrick Akono Ntonga, Henri Gabriel Tsila, \\ Calvin Tonga, Pasma Mache Nkouandou, Christelle Awansi Djeukam, \\ Rachel Ngaha, Odette Etoile Ngo Hondt, Romeo Mbongue, Willy Teukam \\ Soh, Ronny Kojom Kamga, Loic Kojom Foko, Pierre Michel Jazet \\ Dongmo and Chantal Menut
}

DOI: https://doi.org/10.22271/j.ento.2020.v8.i6l.7949

\section{Abstract}

This study assessed the in vitro anti-plasmodial on and larvicidal activity of essential oils from the leaves of Cupressus macrocarpa, Lantana camara and Psidium littorale. The chemical compositions of the different oils were determined. The toxicity of the oils was tested on An. gambiae larvae according to WHO protocol and their in vitro anti-plasmodial activity was assessed by radio-isotopic method. $\alpha$ pinene $(20.78 \%)$, $\beta$-caryophyllene (20.37\%) and 1,8-cineole (eucalyptol) (39.55\%) were the major compounds in Cupressus macrocarpa, Lantana camara and Psidium littorale oils respectively. The in vitro anti-plasmodial activity showed that Lantana camara essential oil is more effective (IC50=12.34 ppm) than Cupressus macrocarpa (147.29 ppm) and Psidium littorale (115.45ppm). Essential oil of Lantana camara showed higher activity on larvae from Yassa (DL=7.37 ppm) while that of Psidium littorale was more active on larvae from Youpwe $(\mathrm{DL}=49.2 \mathrm{ppm})$. These oils can be used for the development of new biocides and natural anti-malarial drugs.

Keywords: Cupressus macrocarpa, Lantana camara, Psidium littorale, Anopheles gambiae s.l., larvicidal activity, anti-plasmodial activity

\section{Introduction}

More than a century after the discovery of its causal agent and the role of the mosquitoes belonging to the 'Anopheles' genus in its transmission, malaria remains one of the most dreaded diseases ${ }^{[1]}$. Approximately 154-289 million people are infected each year, with $80 \%$ of cases occurring in sub-Saharan Africa. Children less than 5 years old, pregnant women, people living with HIV/AIDS, naive migrants, mobile populations and travellers are the most vulnerable ${ }^{[2]}$. Endemic countries are deploying various malaria control means including vector control activities and adequate patient management based on early diagnosis and administration of effective therapies. Despite the $21 \%$ drop in prevalence recorded worldwide between 2010 and $2015^{\text {[3] }}$, the situation remains a cause for concern. This may owe to rough application of the recommended preventive and curative measures, and above all, in the dual resistance of vectors to insecticides and Plasmodium to antimalarial drugs. With regard to vectors, use of DDT and pyrethroids in both agriculture and public health has resulted in the selection of resistant strains ${ }^{[4,5]}$. In recent years, the emergence of Anopheles strains resistant to synthetic insecticides has been reported in many African countries including Benin ${ }^{[6]}$, Côte d'Ivoire $^{[7]}$, Niger ${ }^{[8]}$, Nigeria ${ }^{[9]}$, Equatorial Guinea ${ }^{[10]}$ and Cameroon ${ }^{[11,12]}$. With regard to the parasite, it is known that self-medication, utilization of drugs from street vendors and noncompliance with prescribed doses are responsible for the development of resistant strains of Plasmodium ${ }^{[13]}$. The emergence and spread of resistant strains of Plasmodium and vectors in sub-Saharan Africa is jeopardising malaria control efforts in endemic countries. In this context, the search for natural molecules with effective biological properties is essential. Plants from the Cameroonian flora have for millennia been an inexhaustible source of new molecules that simply need to be explored. Numerous studies have been carried out, highlighting the insecticidal activity of plant species from Cameroonian flora ${ }^{[14,15,16,17]}$. 
They demonstrated that plants insecticidal activities boosted when used in the form of essential oils ${ }^{[18]}$. Volatile essences have several functional groupings and can easily diffuse across the cell membranes ${ }^{[19]}$. Essential oils can therefore be useful for malaria treatment and vector control ${ }^{[20,15] .}$

Cupressus macrocarpa, Lantana camara and Psidium littorale are plants of the Cameroonian flora traditionally used by the population as insect repellents and treatment of many diseases including amoebiasis and malaria ${ }^{[21]}$. The traditional use of these plants attest to their potential as reservoirs of active molecules against malaria parasites and vectors. However, this is still to be investigated. The present study aims to evaluate the in vitro insecticidal and antiplasmodial activities of essential oils from Cupressus macrocarpa, Lantana camara and Psdium littorale leaves.

\section{Materials and Methods \\ Collection of plants and extraction of essential oils}

The plants were chosen because of their traditional use as insect repellents and treatment of certain diseases in many villages of the West region of Cameroon. Plants were collected in September 2018 in Bandjoun and Douala, free of insecticide treatment. The specimens were then identified by botanists from the Department of Plant Organism Biology of the University of Douala. The leaves of each plant species were washed with spring water, cut into small units and then subjected to hydrodistillation for 5 hours using a Clevengertype equipment. The essential oil collected at the end of the distillation process was filtered on an anhydrous sodium sulphate column, then stored in a dark, hermetically sealed glass bottles at $4^{\circ} \mathrm{C}$.

\section{Analysis of the chemical composition by GC and GC/MS}

The chemical analysis of essential oils was carried out using a Varian CP-3380 type chromatograph equipped with a flame ionisation detector and a capillary column (length $30 \mathrm{~m}$, internal diameter $0.25 \mathrm{~mm}$ ) with an apolar stationary phase of the methylsilicone type (DB-1, film thickness $0.25 \mu$ ). Nitrogen was used as carrier gas with $0.8 \mathrm{ml}$.min- 1 flow rate. The temperature of the injector was $220^{\circ} \mathrm{C}$; the detector at $250^{\circ} \mathrm{C}$. The furnace was programmed from $50^{\circ} \mathrm{C}$ to $200^{\circ} \mathrm{C}$ with a temperature gradient of $5^{\circ} \mathrm{C}$.min- 1 . The retention indices of the different constituents was calculated in relation with the retention times of a series of n-alkanes and their relative percentages calculated by electronic integration, considering that their response factors are all equal to 1 .

The gas chromatography-mass spectrometry coupling was done using a Hewlett Packard HP 5970 A apparatus, equipped with an apolar capillary column (30 m x $0.25 \mathrm{~mm}$ ) in HP-1 fused silica (film thickness $0.25 \mu$ ) and a quadrupole detector (ionisation energy $70 \mathrm{eV}$ ). The temperature of the injector was $220^{\circ} \mathrm{C}$ and that of the interface area was $210^{\circ} \mathrm{C}$. Injection in split mode (1/100) of $1 \mu \mathrm{l}$ of a $10 \%$ solution of essential oil in dichloromethane. The furnace temperature was programmed from $70^{\circ} \mathrm{C}$ to $200^{\circ} \mathrm{C}$ with a gradient of $10^{\circ} \mathrm{C}$.min- 1 . Helium was used as carrier gas with $0.6 \mathrm{ml} . \mathrm{min}-1$ flow rate. The acquisition was performed in scan mode [35-300 amu] at 2.96 scan.sec-1.

The identification of the constituents of the essential oils was made on the basis of their retention indices and mass spectra by comparison with the data from literature ${ }^{[22]}$.

Collection sites for larvae of Anopheles gambiae s. 1 . Larval collection took place in 2 districts of Douala, namely
Yassa and Youpwe. Yassa (3॰58 N, 949 E) is a peri-urban district in the east of the city. Main activities are agriculture, animal husbandry and trade. This district is also characterised by the presence of soap and oil companies. Pot holes and old vehicle tyres, are main breeding sites for mosquitoes, especially in the rainy season. Youpwé $\left(04^{\circ} 00^{\prime} \mathrm{N}, 09^{\circ} 42^{\prime} \mathrm{E}\right)$ is a densely populated district located in the Wouri river estuary. Urbanisation is poorly controlled and the population lives mainly from fishing and petty trade. The Wouri River is the only permanent breeding ground for mosquito larvae in this area, although some temporary breeding sites may be visible during the rainy season.

\section{Collection and rearing of Anopheles larvae}

Populations of Anopheles species for testing were collected in the larval stage in natural deposits (sewers, gutters, drums, pits, old tyres, pits and tracks, pot holes) using the dipping method ${ }^{[23]}$. Collection took place during the short rainy season (May to July 2019) at the rate of five consecutive days per month, simultaneously in the Youpwe and Yassa. Anopheles larvae were reared in water from the lodges and fed on Tetrababy fish food ${ }^{[24]}$. The adults obtained were morphologically identified ${ }^{[25,26]}$. The males and females of An. gambiae s.l. were crossed to obtain F1 generation larvae that were later on tested.

\section{Cultivation of Plasmodium falciparum}

The chloroquine-resistant FcB1/Colombia strain of $P$. falciparum was maintained on human red blood cells in RPMI 1640 medium, containing 25 mM HEPES, pH 7.3, 2 g/L sodium bicarbonate, $2 \mathrm{~g} / \mathrm{L}$ glucose, penicillin and streptomycin ${ }^{[27]}$. The medium was enriched with $10 \%$ heatactivated human serum. The RBCs and serum used came from the Etablissement Français du Sang. The culture was conducted at $2 \%$ haematocrit, in 25 and $75 \mathrm{~mL}$ vials and maintained in an oxygen-deficient atmosphere at $37^{\circ} \mathrm{C}$. The culture medium was renewed once a day. A Giemsa stained blood smear was taken daily to control parasitaemia.

\section{Larvicidal tests}

These tests consisted of evaluating the mortality of mature stage larvae (L3 and L4) of Anopheles in the presence of diluted solutions of essential oils according to WHO protocol [28]. Twenty larvae were sampled using a Pasteur pipette and placed in bowls of $8 \mathrm{~cm}$ diameter each containing $99 \mathrm{ml}$ of well water to which $1 \mathrm{ml}$ of diluted test solution was added. Preliminary experiments enabled the selection of a range of concentrations for the tests. Stock solutions of essential oils from each sample were prepared in $90^{\circ}$ ethanol. From these, dilutions were made to obtain final experimental concentrations of 50, 100 and $150 \mathrm{ppm}$. Three repetitions were carried out for each dilution. Two control bowls were also prepared under the same conditions as the test bowls. These negative control contained only ethanol (in the same proportions as for the tests, i.e. 1\%) with no trace of essential oil. Larval counts were carried out every 5 minutes for 1 hour; then every hour for 10 hours and finally after 24 hours of exposure to volatile extracts solubilised in water.

\section{Antiplasmodial test}

The in vitro anti-plasmodial activity of essential oils has been evaluated by the radioisotopic method ${ }^{[29]}$. This method determines the inhibition of parasite growth in culture in the presence of various concentrations of molecules by measuring 
the incorporation of $[3 \mathrm{H}]$ hypoxanthine in the parasite nucleic acids. The experiment was carried-out in 96-well plates as described by Guillon et al. ${ }^{\text {[30] }}$. Briefly, serial dilutions of essential oils were prepared in culture medium and added to asynchronous parasite cultures (1\% parasitaemia, 1\% final haematocrit, $200 \mu \mathrm{L}$ final volume per well) for $24 \mathrm{~h}$, at $37^{\circ} \mathrm{C}$, before addition of $0.5 \mu \mathrm{Ci}$ of $[3 \mathrm{H}]$ hypoxanthine (1-5 $\mathrm{Ci} / \mathrm{mmol}$; Amersham, Les Ulis, France) per well for $24 \mathrm{~h}$. The plates were incubated at $37^{\circ} \mathrm{C}$ in a humid, oxygen-deficient atmosphere. Freezing plates at $-80^{\circ} \mathrm{C}$ interrupted the experiments. After thawing, the contents of the wells were collected on glass fibre filters (Wallac ${ }^{\circledR}$, USA) using a cell collector (Filter Harvester, USA). After adding scintillation fluid (Perkin Elmer ${ }^{\circledR}$, USA), the radioactivity (counts per minute) was measured using a spectrophotometer (450Microbeta Trilux, USA). The growth inhibition for each concentration was determined by comparing the radioactivity incorporated in the treated culture with that of the control (essential oil-free) culture on the same plate. The concentration causing 50\% inhibition (IC50) was obtained from the drug concentration-response curve and the results were expressed as the mean \pm standard deviations determined from at least three independent experiments.

To avoid inhibition of parasite growth due to diffusion of essential oils from neighbouring wells, preliminary tests were conducted to determine the highest essential oil concentration for which such inhibition was not measured. For this purpose, the crude essential oil was only diluted in series with culture medium in one row of a plate, the other row containing only culture medium. Parasites were added to all wells of the plate and the plate was treated as described above. The highest concentration of essential oil showing no inhibition of parasite growth in the surrounding wells was used as a starting concentration to further determine the intrinsic antiplasmodial activity of the essential oil.

\section{Statistical analysis}

Statistical analyses were carried out using Statview version 5.0 software (SAS Institute, Inc, USA). Kruskal Wallis Htests was used to compare larval mortalities. The regression curve from Henry's simplified table which transforms the mortality percentages into probits ${ }^{[31]}$ made it possible to determine the $\mathrm{LC}_{50}$ and $\mathrm{LC}_{95}$. Statistical significance was set at a probability value of less than 0.05 .

\section{Results and Discussion}

The present study shows that the leaves of Cupressus macrocarpa $(0.673 \%)$ have a higher essential oil content than those of Psidium littorale (0.118\%) and Lantana camara
$(0.076 \%)$ (Table 1). These yields contrast with results from Sousa et al. ${ }^{[32]}$, Lídia et al. ${ }^{[33]}$, and Nacira \& Yousra ${ }^{[34]}$. The difference in yields can be related to extraction method, climatic conditions, geographical location of the harvest site, harvest period, and physiopathological state of the plant at the time of harvest ${ }^{[35,14]}$.

Table 1: Data on essential oils from plants collected in Cameroon

\begin{tabular}{|c|c|c|c|c|c|}
\hline \multicolumn{3}{|c|}{ Plant } & \multicolumn{2}{c|}{ Collection } & Essential oil \\
\hline Family & species & Organ & Area & Date & Color Outputs \\
\hline Verbenaceae & $\begin{array}{c}\text { Lantana } \\
\text { camara }\end{array}$ & Leaves & Douala & 24.09 .2018 yellow & $0.076 \%$ \\
\hline Cupressaceae & $\begin{array}{c}\text { Cupressus } \\
\text { macrocarpa }\end{array}$ & Leaves & Bandjoun & 18.09 .2018 yellow & $0.673 \%$ \\
\hline Myrtaceae & $\begin{array}{c}\text { Psidium } \\
\text { littorale }\end{array}$ & Leaves & Douala & 26.09 .2018 yellow & $0.118 \%$ \\
\hline
\end{tabular}

\section{Chemical composition}

The chemical composition of the essential oils of the three plants is given in Table 2. Monoterpenes constitute the major fraction $(50.27 \%$ - $89 \%)$. These monoterpenes were dominated by $\alpha$-pinene $(20.78 \%)$ in the oil of Cupressus macrocarpa. Similar results were obtained with samples from Argentina and Greece ${ }^{[36,37,38]}$. In addition, it should be noted that $\alpha$-pinene has been reported to be the major component of essential oils of other species of the genus Cupressus, notably Cupressus arizonica from Tunisia, Cupressus atlantica from Morocco and Cupressus simpervirens from Algeria [39, 40]. From the above, it should be suggested that $\alpha$-pinene is the characteristic molecule of the essential oils of Cupressus, although it was shown that neral and $\alpha$-terpineol were the major compounds in Cupressus macrocarpa from Egypt had [41, 42]. $\beta$-Caryophyllene (20.37\%) was the majority compound in the essential oil of Lantana camara. Some works have shown a certain variability in the chemical composition of this plant species according to the collection site with $\beta$ caryophyllene as the majority compound for the sample from Egypt [43]; (E)-nerolidol for the sample from Cuba [44]; davanone for the sample from Nepal, sabinene for the sample from Yeme ${ }^{[45]}$.

Psidium littorale is mainly composed of 1,8-Cineole (eucalyptol) (39.55). Although this result corroborates those recorded by Scur et al. ${ }^{[46]}$ and Marques et al. ${ }^{[47]}$, it contrasts with the results recorded by Soliman et al. ${ }^{[48]}$ and Adam et al. [49]. The later showed that $\beta$-Caryophyllene was the major compound in the samples of Psidium littorale originating from Egypt and French Polynesia. Thus, there is a certain variability in the chemical composition of Psidium littorale oil according to the collection site.

Table 2: Chemical composition of essential oils of Cupressus macrocarpa, Lantana camara and Psidium littorale.

\begin{tabular}{|c|c|c|c|c|}
\hline & \multirow{2}{*}{ Compounds } & \multicolumn{3}{|c|}{ \% Composition } \\
\hline IK & & Cupressus macrocarpa & Lantana camara & Psidium littorale \\
\hline \multicolumn{5}{|c|}{ Monoterpenes } \\
\hline \multicolumn{5}{|c|}{ Monoterpenes hydrocarbon } \\
\hline 911 & Tricyclene & -- & -- & -- \\
\hline 928 & $\alpha$-thujene & 1.51 & 0.52 & 4.36 \\
\hline 936 & $\alpha$-pinene & 20.78 & 3.9 & -- \\
\hline 949 & $\alpha$-fenchene & 0.45 & -- & -- \\
\hline 951 & camphene & -- & 1.46 & -- \\
\hline 963 & Furfural $<$ S-methvl & -- & -- & 1.37 \\
\hline 978 & $\beta$-pinene & 8.81 & 17.99 & 0.32 \\
\hline 990 & myrcene & 3.64 & 1.93 & 0.41 \\
\hline 1,006 & p-Terpinène & -- & 0.18 & -- \\
\hline 1,007 & $\alpha$-phellandrene & -- & -- & 0.81 \\
\hline
\end{tabular}




\begin{tabular}{|c|c|c|c|c|}
\hline 1,013 & $\delta$-3-carene & 4.97 & 1.5 & -- \\
\hline 1,019 & $\alpha$-terpinene & 1.8 & 0.28 & -- \\
\hline 1,026 & P-cymene & 0.95 & -- & -- \\
\hline 1,033 & Limonene & 9.96 & -- & -- \\
\hline \multicolumn{5}{|c|}{ Oxygenated monoterpenes } \\
\hline 1,037 & 1,8-Cineole (eucalyptol) & -- & -- & 39.55 \\
\hline 1,046 & cis- $\beta$-ocimene & -- & 0.89 & -- \\
\hline 1,059 & trans- $\beta$-ocimene & -- & 0.56 & -- \\
\hline 1,060 & G-terpinene & 2.95 & -- & -- \\
\hline 1,070 & $\gamma$-terpinene & -- & 0.58 & -- \\
\hline 1,091 & Terpinolene & 3.38 & -- & -- \\
\hline 1,101 & Linalool & 4 & 14.68 & -- \\
\hline 1,102 & 2-Methylbutyl 2-methylbutyrate & -- & 0.29 & -- \\
\hline 1,125 & Cis-p-menth-2-en-1-ol & 2.56 & -- & -- \\
\hline 1,128 & cis-Menth-2-en-1-ol & -- & -- & 0.68 \\
\hline 1,150 & Cis- $\beta$-terpineol & 0.27 & -- & -- \\
\hline 1,151 & Lilac aldehyde D & -- & 1.06 & -- \\
\hline 1,163 & Trans- $\beta$-terpineol & 0.44 & -- & -- \\
\hline 1,166 & Terpineol $<5$ - $>$ & -- & -- & 1.17 \\
\hline 1,172 & terpinen-4-ol & 9.21 & 0.76 & -- \\
\hline 1,183 & neo-dihydro carveol & -- & 1.35 & -- \\
\hline 1,187 & $\alpha$-terpineol & 6.01 & -- & -- \\
\hline 1,196 & Methyl salicylate & -- & 0.89 & -- \\
\hline 1,196 & Cis-Piperitol & 0.83 & -- & -- \\
\hline 1,252 & Piperitone & 0.56 & -- & -- \\
\hline 1,270 & Cinnamaldehyde $\left\langle(\mathrm{E})^{\prime}\right\rangle$ & -- & -- & 0.15 \\
\hline 1,287 & Bornyl acetate & 0.13 & -- & -- \\
\hline 1,299 & 2-cis-dihydro acétate de tepinyl & 0.2 & -- & -- \\
\hline 1,315 & Déca-(2E,4E)-dien-1-ol & 0.18 & -- & -- \\
\hline 1,322 & Hexyl 2-methyl-3-pentenoat & -- & -- & 0.48 \\
\hline 1,352 & $\alpha$-acétate-terpinyl & 2.18 & -- & -- \\
\hline 1,363 & Cyclosativene & 1.32 & -- & -- \\
\hline 1,364 & Anisaldehyde <dirnethylacetal'p-> & -- & -- & 0.97 \\
\hline \multicolumn{5}{|c|}{ Sesquiterpenes } \\
\hline \multicolumn{5}{|c|}{ hydrocarbonated Sesquiterpenes } \\
\hline 1,383 & Longifolene & 0.13 & -- & -- \\
\hline 1,384 & $\beta$-Bourbonene & -- & 0.57 & -- \\
\hline 1,388 & $\alpha$-copaene & -- & -- & 5.62 \\
\hline 1,399 & p-Elemene & -- & 0.85 & -- \\
\hline 1,416 & $\beta$-Caryophyllene & -- & 20.37 & 0.72 \\
\hline 1,427 & (E)-Caryophyllene & -- & -- & 0.69 \\
\hline 1,430 & ß-Copaene & 0.46 & -- & 2.63 \\
\hline 1,442 & (+)-Aromandrene & -- & -- & 0.28 \\
\hline 1,455 & $\alpha$-humulene & 0.57 & -- & 0.28 \\
\hline 1,474 & G-muurolene & 1.59 & -- & -- \\
\hline 1,485 & D-germacrene & 0.51 & 8.79 & 0.68 \\
\hline 1,489 & $\alpha$-selinene & -- & -- & 1.39 \\
\hline 1,494 & Bicyclogermacrene & -- & 2.22 & -- \\
\hline 1,495 & Trans- $\beta$-guaiene & -- & -- & 0.7 \\
\hline 1,500 & $\beta$-bisabolene & -- & ---- & 1.17 \\
\hline 1,508 & A-germacrene & 1.61 & 4.7 & \\
\hline 1,509 & $\gamma$-Cadinene & -- & -- & 2.35 \\
\hline 1,519 & Nookatene & -- & -- & 1.06 \\
\hline 1,524 & $\Delta$-cadinene & 1.42 & -- & -- \\
\hline 1,524 & $\delta$-Cadinene & 0.3 & 0.28 & 0.46 \\
\hline 1,532 & Davana ether & -- & 0.21 & -- \\
\hline 1,533 & $\alpha$-calacorene & -- & -- & 0.21 \\
\hline 1,540 & trans-Cadina-1,4-diene & -- & -- & 1.49 \\
\hline 1,563 & 7-Hydroxyfarnesene & -- & 0.8 & -- \\
\hline 1,564 & $\alpha$-Cadinène & 0.16 & -- & -- \\
\hline \multicolumn{5}{|c|}{ Oxygenated Sesquiterpenes } \\
\hline 1,517 & Cubebol & -- & -- & 2.94 \\
\hline 1,532 & 10-epi-Cubebol & 2.7 & -- & -- \\
\hline 1,568 & (E)-Nerolidol & -- & -- & 1.96 \\
\hline 1,569 & Longipinanol & -- & 3.65 & -- \\
\hline 1,592 & viridiflorol & -- & 0.23 & -- \\
\hline 1,595 & Fokienol & -- & 0.28 & -- \\
\hline 1,600 & Oxyde de caryophyllène & -- & -- & 0.31 \\
\hline
\end{tabular}




\begin{tabular}{|c|c|c|c|c|}
\hline 1,600 & $\beta$-atlantol & -- & 0.59 & -- \\
\hline 1,619 & 1,10-di-epi-Cubenol & 0.48 & -- & -- \\
\hline 1,622 & Cubenol-1-epi & -- & -- & 0.46 \\
\hline 1,625 & diidromircene,1,6-diol-Z & -- & 0.67 & -- \\
\hline 1,643 & Cubenol & -- & -- & 1.52 \\
\hline 1,645 & Humulène époxyde I & 1.1 & -- & -- \\
\hline 1,648 & $\alpha$-Muurolol & -- & -- & 0.88 \\
\hline 1,650 & $\alpha$-Cadinol & 1.25 & 2.47 & 0.81 \\
\hline 1,661 & $(\mathrm{E}, \mathrm{E})$-Farnesol & -- & -- & 0.38 \\
\hline 1,668 & $\gamma$-Eudesmol & 1.11 & -- & -- \\
\hline 1,669 & 14-Hydroxy-9-epi-(E)-caryophyllene & -- & 1.61 & -- \\
\hline 1,673 & epi- $\beta$-Bisabolol & -- & -- & 2.87 \\
\hline 1,683 & $\alpha$-Bisabolol & -- & -- & 8.56 \\
\hline 1,692 & $\alpha$-Eudesmol & 0.68 & -- & -- \\
\hline 1,697 & Shyobunol & -- & -- & 2.43 \\
\hline 1,722 & (E)-Nerolidol acetate & -- & 0.21 & 1.18 \\
\hline 1,729 & (2Z,6E)-Farnesol & -- & -- & 2.21 \\
\hline 1,820 & (E,E)-Farnesyl acetate & -- & -- & 0.69 \\
\hline
\end{tabular}

\section{Biological Tests}

\section{- Larvicidal tests}

Larvicidal tests have shown that the essential oils of the leaves of Cupressus macrocarpa, Psidium littorale and Lantana camara have important biological properties against Anopheles gambiae s.l. However, the level of effectiveness seems to depend on the plant species, the concentration used and the site of collection of the Anopheles gambiae s.l. strain (Tables 3,4). LC50 and LC95 values determined from Henry's simplified table were used to classify essential oils according to their toxicity level on An. gambiae s.l. larvae. Essential oil of Psidium littorale was the most effective, followed by those of Lantana camara and Cupressus macrocarpa (table 4). According to Pellecuer et al. ${ }^{[50]}$, the toxicity of an essential oil is strongly related to its chemical composition. Thus, the larvicidal activity of the essential oils noted in our study would be due to their high monoterpene content. Monoterpenes have long been recognised for their proven larvicidal properties against insects [51, 52, 53]. However, the high toxicity shown by the essential oil of Psidium littorale compared to those of Cupressus macrocarpa and Lantana camara is thought to be due to Cubebol. This molecule is present in Psidium littorale oil but is absent in those of
Cupressus macrocarpa and Lantana camara. The work of Hui-Jing et al. ${ }^{[54]}$ highlighted the role played by this molecule in its pure state when evaluating the insecticidal activity of the ethanoic extract of Cryptomeria japonica on larvae of Aedes albopictus and Aedes aegypti. Furthermore, our results show that, for certain concentrations and for the same plant species, mean mortality numbers were significantly different for $A n$. gambiae larvae from different collection sites (Tables 3 and 4). Thus, larvae collected in Yassa were more sensitive to essential oils than those collected in Youpwé. This result could be explained by the fact that Anopheles gambiae s.l. is a species complex ${ }^{[55,56]}$. Studies have shown that of the species in the complex, An. coluzzii is the one that has developed the most adaptive characteristics to pollutants in poorly urbanised neighbourhoods in African cities, whereas An. gambiae s.s prefers peripheral neighbourhoods where the environment is still relatively natural ${ }^{[56,57]}$. It should therefore be suggested that the strain collected in Yassa that is more sensitive to essential oils would be An. gambiae s.s, while the less sensitive strain from Youpwe would be An. coluzzii. However, a molecular analysis should be carried out to confirm this hypothesis.

Table 3: Sensitivity of mature larvae of Anopheles gambiae s. l. to different concentrations of essential oils of Psidium littorale, Lantana camara and Cupressus macrocarpa, after 10 hours of exposure (Kruskal Wallis H-test and Mann-Withney Z-test, $P<0.05$ ).

\begin{tabular}{|c|c|c|c|c|c|}
\hline & & \multicolumn{2}{|c|}{ Mature larvae } & Z-test & P -value \\
\hline Essential oils & Concentration (ppm) & Yassa & Youpwe & & \\
\hline Psidium littorale & 150 & $20 \pm 0.577$ & $20 \pm 0.0$ & -0.655 & 0.5127 \\
\hline & 100 & $19 \pm 1.155$ & $17 \pm 1.528$ & -1.091 & 0.2752 \\
\hline & 50 & $16 \pm 3.215$ & $13 \pm 4.041$ & -1.091 & 0.2752 \\
\hline & H-test & 2.022 & 7.200 & -- & -- \\
\hline & P-value & 0.368 & $0.0273^{*}$ & -- & -- \\
\hline Lantana camara & 150 & $19 \pm 1.732$ & $17 \pm 0.577$ & -1.528 & 0.1266 \\
\hline & 100 & $18 \pm 1.000$ & $10 \pm 2.646$ & -1.622 & 0.0495 \\
\hline & 50 & $17 \pm 2.309$ & $5 \pm 1.732$ & -1.964 & 0.0495 \\
\hline & H-test & 1.622 & 7.200 & -- & -- \\
\hline & P-value & 0.444 & $0.0273^{*}$ & -- & -- \\
\hline Cupressus macrocarpa & 150 & & & & \\
\hline & 100 & $18 \pm 1.528$ & $11 \pm 1.528$ & -1.964 & 0.0495 \\
\hline & 50 & $7 \pm 3.732$ & $09 \pm 0.0$ & -1.964 & 0.0495 \\
\hline & H-test & 5.600 & 6.200 & -- & -- \\
\hline & P-value & 0.060 & $0.045 *$ & -- & -- \\
\hline
\end{tabular}

*Statistically significant 
Table 4: Lethal doses of essential oils capable of causing 50\% and 95\% mortality of mature larvae collected in the Youpwe and Yassa districts (Douala).

\begin{tabular}{|c|c|c|c|c|}
\hline \multirow{2}{*}{ Plants } & \multicolumn{3}{|c|}{ Lethals doses } \\
\cline { 2 - 5 } & \multicolumn{2}{|c|}{ DL50 } & \multicolumn{2}{c|}{ DL95 } \\
\hline & Yassa & Youpwe & Yassa & Youpwe \\
\hline Cupressus macrocarpa & 60.445 & 125.395 & 170.827 & 432.78 \\
\hline Lantana camara & 25.088 & 83.657 & 167.177 & 250.939 \\
\hline Psidium littorale & 7.337 & 49.275 & 97.897 & 88.407 \\
\hline
\end{tabular}

\section{Antiplasmodial test}

The essential oils of the three plants have shown some in vitro antiplasmodial activity against Plasmodium falciparum. However, the essential oil of Lantana camara (IC50=12.34 ppm) appears to be the most active, followed by that of Psidium littorale (IC50=115.455 ppm) and Cupressus macrocarpa (IC50=147.29 ppm) (figure 1). The strong antiplasmodial activity could be related to the high Linalol content of Lantana camara essential oil (14.68\%). Terpenes such as farnesol, nerolidol, limonene, and linalol are known for in vitro inhibition of the biosynthesis of dolichol in the trophozoite and schizontal cycle of $P$. falciparum. Terpenes also have the ability to inhibit the biosynthesis of the isoprenic side chain of benzoquinone in the schizogonic cycle [58, 59, 60]. Based on their IC50 values, essential oil of Lantana camara has a moderate in vitro toxicity against Plasmodium falciparum, whereas those of Cupressus macrocarpa and Psidium littorale show no significant activity.

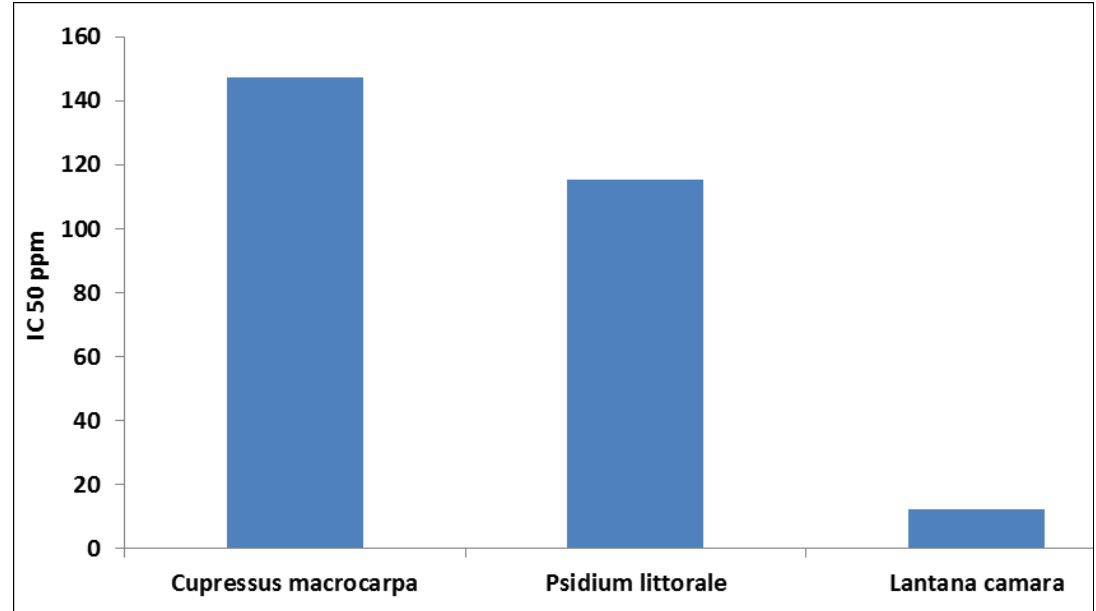

Fig 1: Summary diagram of the anti-plasmodial activity of essential oils on Plasmodium falciparum in vitro

\section{Conclusion}

The present study has shown that Psidium littorale and Lantana camara have important larvicidal properties against Anopheles gambiae s.l. while Lantana camara has moderate activity against $P$. falciparum in vitro. These plants can therefore be considered as a source of new molecules against malaria germs and vectors.

Acknowledgements: The authors would like to thank the inhabitants of Yassa and Youpwe for their collaboration.

\section{References}

1. Carnevale et Robert. Les anophèles Biologie, transmission du Plasmodium et lutte antivectorielle. IRD Éditions, collection didactique 2009,402.

2. WHO Malaria 2020. https://www.who.int/newsroom/fact-sheets/detail/malaria. 09 November 2020.

3. WHO. 2017. Global response to malaria at crossroads. https:/www.who.int/fr/news-room/detail/29-11-2017global-response-to-malaria-at-crossroads. 17 janvier 2020.

4. Chandre F, Darriet F, Manguin S, Brengues C, Carnevale P, Guillet P. Pyrethroid cross resistance spectrum among populations of Anopheles gambiae S.S. from Cote d'Ivoire. Journal of the American Mosquito Control Association 1999;15:53-59.

5. Diabate A, Baldet $\mathrm{T}$, Chandre F, Akogbeto M, Guiguemde TR, Darriet F et al. The role of agricultural use of insecticides in resistance to pyrethroids in Anopheles gambiae sl in Burkina Faso. The American Journal of Tropical Medicine and Hygiene 2002;67:617622.

6. Aikpon R, Agossa F, Osse R, Oussou O, Aizoun N, OkeAgbo $\mathrm{F}$ et al. Resistance in Anopheles gambiae s.l. populations from Atacora department in Benin, West Africa: a threat for malaria vector control. Parasit Vectors 2013;6:192-198.

7. Ahoua ALP, Koffi AA, Adja MA, Assi SB, Kouassi PK, N'Guessan R. Status of pyrethroid resistance in Anopheles gambiae s.s. $\mathrm{M}$ form prior to the scaling up of Long Lasting Insecticidal Nets (LLINs) in Adzope, Eastern Cote d'Ivoire. Parasit Vectors 2012;5:289-294.

8. Czeher C, Labbo R, Arzika I, Duchemin J-B. Evidence of increasing Leu-Phe knockdown resistance mutation in Anopheles gambiae from Niger following a nationwide long-lasting insecticide-treated nets implementation. Malaria Journal 2008;7:189-200.

9. Awolola TS, Brooke BD, Hunt RH, Coetzee M. Resistance of the malaria vector Anopheles gambiae s.s. to pyrethroid insecticides, in southwestern Nigeria. Annals of Tropical Medicine and Parasitology 2002;96:849-852.

10. Overgaard HJ, Reddy VP, Abaga S, Matias A, Reddy MR, Kulkarni V et al. Malaria transmission after five years of vector control on Bioko Island, Equatorial Guinea. Parasit Vectors 2012;5:253-266. 
11. Etang J, Chandre F, Guillet P, Manga L. Reduced bioefficacy of permethrin EC impregnated bednets against an Anopheles gambiae strain with oxidase-based pyrethroid tolerance. Malaria Journal 2004;3:46-52.

12. Nwane P, Etang J, Chouaibou M, Toto J, Koffi A, Mimpfoundi R. Multiple insecticide resistance mechanisms in Anopheles gambiae s.l. populations from Cameroon, Central Africa. Parasit Vectors 2013;6:41-54.

13. Pradines B, Dormoi J, Briolant S, Bogreau H. La résistance aux antipaludiques. Revue francophone des laboratoires 2010;422:51-62.

14. Tchoumbougnang F, Dongmo PMJ, Sameza ML, Mbanjo EGN, Fotso GBT, Zollo PHA et al. Larvicidal activity against Anopheles gambiae Giles and chemical composition of essential oils from four plants cultivated in Cameroon. Biotechnology, Agronomy, Society and Environment 2009;13(1):77-84.

15. Foko NP, Baldovini N, Mouray E, Mambu L, Belong P, Grellier P. Activity of Ocimum basilicum, Ocimum canum, and Cymbopogon citratus essential oils against Plasmodium falciparum and mature-stage larvae of Anopheles funestus S.S. Parasite 2014;21:33. doi: 10.1051/parasite/2014033. Epub 2014 Jul 7

16. Akono NP, Jazet DPM, Tonga C, Mache NP, Kekeunou S. Evaluation de la toxicité des huiles essentielles des feuilles de Callistemon citrinus, Cinnamomum zeylanicum et Psidium guajava sur les adultes d'Anopheles coluzzii Coetzee et Wilkerson 2013, vecteur du paludisme urbain au Cameroun. Cameroon Journal of Biological and Biochemical Sciences 2017;25:12-21.

17. Foko G, Tamesse J, Messi J. Insecticidal effects of Capsicum annuum on Anopheles gambiae Giles under laboratory conditions. Journal of Entomology 2007;4(4):299-307.

18. Ndomo A, Tapondjou L, Tendonkeng F, Mbiopo T. Evaluation des propriétés insecticides des feuilles de Callistemon viminalis (Myrtaceae) contre les adultes d'Acanthoscelides obtectus (Say) (Coleoptera; Bruchidae). Tropicultura 2009;27(3):137-143.

19. Boyom FF, Ngouana V, Zollo PH, Menut C, Bessiere $\mathrm{JM}$, Gut $\mathrm{J}$ et al. Composition and anti-plasmodial activities of essential oils from some Cameroonian medicinal plants. Phytochemistry 2007;64(7):1269-1275.

20. Lucia A, Licastro S, Zerba E, Audino PG, Masuh H. Sensitivity of Aedes aegypti adults (Diptera: Culicidae) to the vapors of Eucalyptus essential oils. Bioresource technology 2009;100(23):6083-6087.

21. Mpondo EM, Dibong SD, Pouha M. Etude Ethnobotanique des plantes médicinales utilisées dans le département du Haut-Nkam (Sud Cameroun). International Journal of Innovation and Applied Studies 2017;21(4):574-595.

22. Adams RP. Identification of essential oils by gas chromatography quadrupole mass spectroscopy. Carol Stream, IL, USA: Allured Publishing Corporation 2001,469.

23. Service MW. Mosquito Ecology: Field sampling methods, 2nd edition, Elesevier, Ampplied Science Publisher, London 1993,988.

24. Desfontaines M, Tchikangwa I, Le Goff G, Robert V, Carnevale P. Influence de l'alimentation des larves d'Anopheles gambiae (Diptera, Culicidae) sur le développement préimaginal en insectarium. Bulletin de liaison et de documentation de l’O.C.E.A.C 1991;98:12-
14.

25. Gillies MT, Coetzee M. A Supplement to the Anophelinae of Africa South of the Sahara. (Afrotropical Region) Publications of the South African Institute for Medical Research 1987;55:1-143.

26. Gillies MT, De Meillon B. The Anophelinae of Africa south of the Sahara (Ethiopian Zoogeographical Region). Publications of the South African Institute for Medical Research 1968;54:343.

27. Trager W, Jensen JB. Human malaria parasites in continuous culture. Science 1976;193:673-675.

28. WHO (World Health Organization). Bioassay method for the titration of Bacillus sphaericus: consultation on the development of Bacillus sphaericus as a microbial larvicide. World Health Organization 1985;3:85-95.

29. Desjardins RE, Graig JC, David H, Jeffrey DC. Quantitative assessment of antimalarial activity in vitro by a semi-automated micro-dilution technique. Antimicrobial Agents and Chemotherapy 1979;16:710718. [PMC free article] [PubMed] [Google Scholar]

30. Guillon J, Moreau S, Mouray E, Sinou V, Forfar I, Belisle-Fabre $\mathrm{S}$ et al. New ferrocenic pyrrolo [1,2-a] quinoxaline derivatives: synthesis, and in vitro antimalarial activity. Bioorganic \& Medicinal Chemistry 2008;16:9133-9144.

31. Frontier S, Davoult D, Gentilhomme V, Langadeuc Y. Statistique pour les sciences de la vie et de l'environnement: Cours et exercices corrigés. Dunod, Paris 2001,410.

32. Sousa EO, Barreto FSS, Rodrigues FFG, Campos AR \& Costa JGM. Chemical composition of the essential oils of Lantana camara L. and Lantana montevidensis Briq. and their synergistic antibiotic effects on aminoglycosides. Journal of Essential Oil Research 2012;24:447-452.

33. Lídia BP, Medeiros, Márcio dos S, Rocha, Sidney Gde L, Gustavo Rde $\mathrm{S}$ et al. Chemical constituents and evaluation of cytotoxic and antifungal activity of Lantana camara essential oils. Revista Brasileira de Farmacognosia Brazilian Journal of Pharmacognosy 2012;22(6):1259-1267

34. Nacira A, et Yousra B. Activité Antimicrobienne de l'Huile Essentielle du Cyprès Vert (Cupressus sempervirens L.). Algerian Journal of Natural Products 2017;5(2):455-462.

35. Vieira RF, Simon JE. Chemical Characterization of Basil (Ocimum spp.) Found in the Markets and Used in Traditional Medicine in Brazil Economic Botany. Published By: Springer 2000,207-216

36. Malizia RA, Cardell DA, Molli JS, González S, Guerra PE, Grau RJ. Volatile constituents of leaf oils from the Cupressaceae family: Part I. Cupressus macrocarpa Hartw C. Arizonian Greene and C. torulosa Don species growing in Argentina. Journal of Essential Oil Research 2000;12:59-63.

37. Adams RP. Geographic variation in the leaf essential oils of Hesperocyparis (cupressus) abramsiana, H. goveniana and H. macrocarpa: systematic implications. Phytologia 2009;91(1):226-243.

38. Giatropoulos A, Pitarokili D, Papaioannou F, Papachristos DP, Koliopoulos G, Emmanouel N et al. Essential oil composition, adult repellency and larvicidal activity of eight Cupressaceae species from Greece against Aedes albopictus (Diptera: Culicidae). Parasitology Research 2013;112:1113-112. 
39. Chéraif I, Ben Jannet H, Hammami M. Chemical composition and antimicrobial activity of essential oils of Cupressus arizonica Greene. Biochemical Systematics and Ecology 2007;35(12):813-820.

40. Boukssaim H, Ghanmi M, Satrani B, Aafi A, Aberchane M, Khia AMSB et al. Caractérisation chimique et microbiologique des huiles essentielles des rameaux, des cônes et du bois de Cupressus atlantica, arbre forestier endémique du Maroc. Phytothérapie 2013;11:294-300.

41. El-Ghorab AH, Khaled FE, Hamdy AS. Effect of drying on the chemical composition of the Egyptian Cupressus macrocarpa (Hartw. ex Gordon) essential oils and their biological characteristics. Journal of Essential Oil Bearing Plants 2007; 10 (5): 399-411.

42. Saad AM, Mohammed MMD, Mosad A, Ghareeb WS, Ahmed MAF. Chemical Composition and Antimicrobial Activity of the Essential Oil of the Leaves of Cupressus macrocarpa Hartweg. ex Gordon. Journal of Applied Pharmaceutical Science 2017;7(09):207-212.43.

43. Abdel-Hady NM, Abdei-Halim AS, Al-Ghadban AMJ. Chemical composition and insecticidal activity of the volatile oils of leaves and flowers of Lantana camara L. cultivated in Egypt Egypt. Journal of the Egyptian Society of Parasitology 2005;35(2):687-98.

44. Satyal Prabodh, Crouch Rebecca A., Monzote Lianet, Cos Paul, Ali Nasser A. Awadh, Al haj Mehdi A., Setzer W N..- The chemical diversity of Lantana camara: analyses of essential oil samples from Cuba, Nepal, and Yemen. Chemistry \& biodiversity 2016;13(3):336-342.

45. Sousa EO, Colares AV, Rodrigues FFG, Campos AR, Lima SG, Costa JGM. Effect of Collection Time on Essential Oil Composition of Lantana camara Linn (Verbenaceae) Growing in Brazil Northeastern. Academy of Chemistry of Globe Publications Records of Natural Products 2010;4(1):31-37.

46. Scur MC, Pintoa FGS., Pandinia JA, Costab WF, Leiteb CW, Temponi LG. Antimicrobial and antioxidant activity of essential oil and different plant extracts of Psidium cattleianum Sabine. Brazilian Journal of Biology. 2016;76(1):101-108.

47. Marques FA, Wendler EP, Sales MBHLN, CoffaniNunes JV, Campana J, Guerrero J PG. Volatile oil of sabine from the Brazilian Atlantic Fores. Psidium cattleianum. Journal of Essential Oil Research 2008;20(6):519-520.

48. Soliman FM, Fathy MM, Salama MM, Saber FR. Comparative study of the volatile oil content and antimicrobial activity of Psidium guajava L. and Psidium cattleianum Sabine leaves. Bulletin of Faculty of Pharmacy, Cairo University. 2016; 54:219-225.

49. Adam F, Vahirua-Lechat I, Deslandes E, Menut C. Aromatic Plants of French Polynesia. V. Chemical Composition of Essential Oils of Leaves of Psidium guajava L. and Psidium cattleyanum Sabine. Journal of Essential Oil Research 2011;23(1):98-101.

50. Pellecuer J, Allegrini J, de Buochberg SM. Huiles essentielles bactéricides et fongicides. Revue de l'Institut Pasteur de Lyon 1976;9:135-159.

51. Kim DH, Ahn YJ. Constituents of Foeniculum vulgare fruit against three coleopteran stored-product insects. Pest Management Science 2001;57:301-306.

52. Park BS, Lee SE, Choi WS, Jeong CY, Song C, Cho KY. Insecticidal and acaricidal activity of piperonaline and piperoctadecalidine derived from dried fruits of Piper longum L. Crop Protect 2002;21:249-51.

53. Papachristos DP, Karamanoli K, Stamopoulos DC, Menkissoglu-Spiroudi U. The relationship between the chemical composition of three essential oils and their Insecticidal activity against Acanthoscelides obtectus (Say). Pest Management Science 2004;60(5):514-20.

54. Hui-jing G, Sen-sung C, Ching-Gi H, Wei-June C, Shang-Tzen C. Mosquito larvicidal activities of extractives from blacl heartwood-type Cryptomeria japonica. Parasitology research 2009;105(5):1455.

55. Fontenille D, Cohuet A, Awono-Ambene PH, AntonioNkondjio C, Wondji C, Kengne P et al. Systématique et biologie des anophèles vecteurs de plasmodium en Afrique, données récentes. Medecine tropicale 2003;63:247-253.

56. Tia E, Chouaibou M, Gbalégba CNG, Boby AMO, Koné $\mathrm{M}$, Kadjo AK. Distribution des espèces et de la fréquence du gène $\mathrm{Kdr}$ chez les populations d'Anopheles gambiae s.s. et d'Anopheles coluzzii dans cinq sites agricoles de la Côte d'Ivoire. Bulletin de la Société de pathologie exotique 2017;110(2):130-134.

57. Mbida MA, Etang J, Akono P, Eboumbou MC, AwonoAmbene P, Tagne D et al. Nouvel aperçu sur l'écologie larvaire d'Anopheles coluzzii Coetzee et Wilkerson, 2013 dans l'estuaire du Wouri, Littoral-Cameroun. Bulletin de la société de pathologie exotique 2017;110(2):92-101.

58. Menezes AMS, Almeida FRC, Rao VSN, Matos MEO. Anti-inflammatory activity of the essential oil of Vanillosmopsis arborea. Fitoterapia 1990;61:252-254.

59. Phillipson JD and Wright CW. Can ethnopharmacology contribute to the development of antimalarial agents? Journal of Ethnopharmacology 1991;32:155-165.

60. Christensen SB, Kharazmi A. Antimalarial natural products: isolation, characterisation and biological properties. In Bioactive compounds from natural sources: isolation, characterization and biological properties, Tringali C (ed). Taylor \& Francis: London 2001,379-432.

\section{Authors Name}

\section{Gaëlle Magne Tamdem,}

Laboratory of Animal Biology and Phsiology, Faculty of Science, Université de Douala. PO Box. 24157 Douala, Cameroon

\section{Patrick Akono Ntonga,}

Laboratory of Animal Biology and Phsiology, Faculty of Science, Université de Douala. PO Box. 24157 Douala, Cameroon

\section{Henri Gabriel Tsila,}

Biology and Applied Ecology Research Unit, Faculty of Science, University of Dschang, PO Box: 067 Dschang, Cameroon

\section{Calvin Tonga,}

Laboratory of Animal Biology and Phsiology, Faculty of Science, Université de Douala. PO Box. 24157 Douala, Cameroon

\section{Pasma Mache Nkouandou}

Laboratory of Animal Biology and Phsiology, Faculty of Science, Université de Douala. PO Box. 24157 Douala, Cameroon 
Christelle Awansi Djeukam

Laboratory of Animal Biology and Phsiology, Faculty of Science, Université de Douala. PO Box. 24157 Douala, Cameroon

\section{Rachel Ngaha}

Laboratory of Animal Biology and Phsiology, Faculty of Science, Université de Douala. PO Box. 24157 Douala, Cameroon

\section{Odette Etoile Ngo Hondt}

Laboratory of Animal Biology and Phsiology, Faculty of Science, Université de Douala. PO Box. 24157 Douala, Cameroon

\section{Romeo Mbongue}

Laboratory of Animal Biology and Phsiology, Faculty of Science, Université de Douala. PO Box. 24157 Douala, Cameroon

\section{Willy Teukam Soh}

Laboratory of Animal Biology and Phsiology, Faculty of Science, Université de Douala. PO Box. 24157 Douala, Cameroon

\section{Ronny Kojom Kamga}

Laboratory of Animal Biology and Phsiology, Faculty of Science, Université de Douala. PO Box. 24157 Douala, Cameroon

\section{Loic Kojom Foko}

Laboratory of Animal Biology and Phsiology, Faculty of Science, Université de Douala. PO Box. 24157 Douala, Cameroon

\section{Pierre Michel Jazet Dongmo}

Laboratory of Biochemistry, Faculty of Science, Université de Douala. PO Box. 24157 Douala, Cameroon

\section{Chantal Menut}

IBMM, Montpellier-UMR 5247, Faculty of Pharmacy, 15 Avenue Charles Flahault, 34093, Montpellier, France 